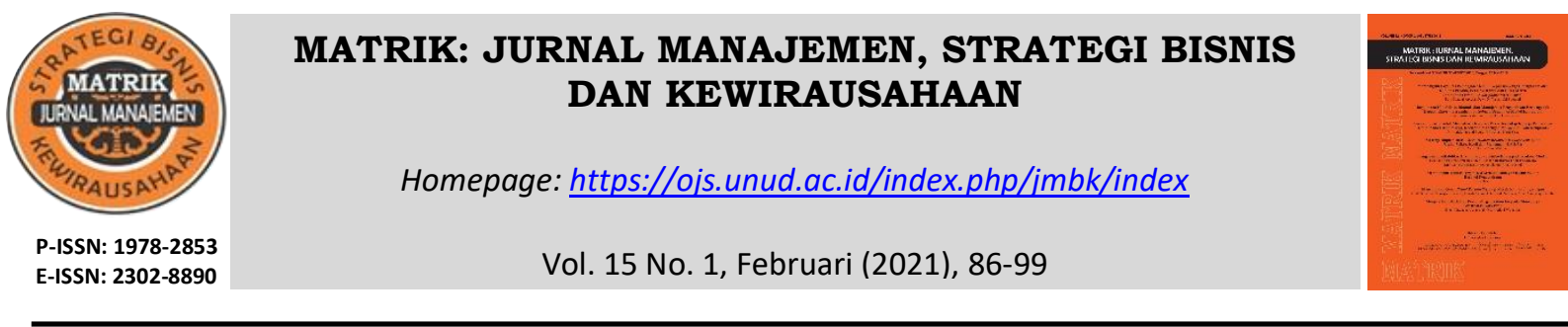

\title{
Intention To Use Self-Service Technology Based on Basic Human Needs
}

\section{Lydia Ari Widyarini}

Universitas Katolik Widya Mandala Surabaya

email: lydiaari@ukwms.ac.id

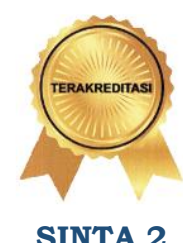

DOI : https://doi.org/10.24843/MATRIK:JMBK.2021.v15.i01.p08

\begin{abstract}
In the context of technology developing in the society, Self-service technologies (SSTs) are becoming increasingly popular in retailing contexts, public service, banking, ticketing, parking, tourism, etc. Previous theories of SST adoption have largely ignored the basic human needs, such as competence, autonomy and relatedness that drive customer motivation and the use of SSTs in Indonesia. We address this theoretical gap and examine selfdetermination theory (SDT) to the Self Service Technology in general. Based on the argument proposed by SDT, self-determined motivation is hypothesized to mediate the relationships between autonomy, competence, and perceived anonymity, and the intention to use SSTs. 253 data collected from respondents's questionnaire and form a structural equation model and support these hypotheses. This research shows that there is relation autonomy and competence to self determination and adoption intention to SSTs. There is no good relation anonymity to self determination and adoption intention to SSTs. There is relation Self Determination to adoption intention to SSTs. Self Determination mediate relationship of autonomy and competence on adoption intention, but Self Determination is not good mediation relationship of perceived anonymity on adoption intention to SSTs.
\end{abstract}

Keywords: self-determination theory, adoption intention, sutonomy, competence, perceived anonymity

\section{Niat Menggunakan Teknologi Swalayan Berdasarkan Kebutuhan Dasar Manusia}

\begin{abstract}
ABSTRAK
Dalam konteks perkembangan teknologi di masyarakat, teknologi swalayan (Self Service Technology) menjadi semakin populer dalam konteks ritel, layanan publik, perbankan, tiket, parkir, pariwisata, dan lain sebagianya. Teori sebelumnya dari adopsi teknologi telah mengabaikan kebutuhan dasar manusia, seperti kompetensi, otonomi dan keterkaitan yang mendorong motivasi pelanggan untuk menggunakan SST di Indonesia. Penelitian ini membahas gab teoritis dikaitkan dengan Self Determination Theory (SDT) pada Self Service Technology secara umum. Berdasarkan SDT, Self Determination Theory dihipotesiskan memediasi hubungan antara otonomi, kompetensi, dan anonimity yang dirasakan, terhadap niat untuk menggunakan SST. 253 data yang dikumpulkan dari penyebarran kuesioner kepada responden membentuk model persamaan struktural dan mendukung hipotesis ini. Penelitian ini menunjukkan bahwa ada pengaruh antara otonomi dan kompetensi terhadap self determination motivation dan niat adopsi pada SST. Tidak ada pengaruh anonimity terhadap self determination motivation dan niat adopsi ke SST. Ada pengaruh self determination motivation terhadap niat adopsi SST. Self determination motivation memediasi hubungan otonomi dan kompetensi pada niat adopsi, tetapi self determination motivation tidak memediasi pengaruh perceived anonimity terhadap niat adopsi untuk SST.
\end{abstract}

Keywords: self-determination theory, adoption intention, autonomy, competence, perceived anonymity 


\section{INTRODUCTION}

The influence of computer and information technology development is expected to provide more freedom for sellers to provide electronic transaction services. Efficiency and effectiveness become the main determinants in the knowledge era. Moreover, customer service is also essential in providing services to consumers. Human interaction-based customer service, which is supported by technology, is developed to improve service quality to consumers through updated information and service whenever they desire.

Technology which has supported customer service for the last few years is called selfservice technology. It is a technology enabling consumers to obtain service without directly involving company's employees. This technology replaces face-to-face service with the employees and aims to conduct more accurate, comfortable, and swift transations without direct interaction with the employees. For instance, airports have flight check-in service using a technology called Kiosk; supermarkets adds self-checkout terminal so consumers can serve themselves when paying their goods; banks employ Automated Teller Machine (ATM) to provide banking services to its clients; fast-food chains provide vending machines; train station uses self-ticketing machine to service consumers in purchasing and printing train tickets; highway payment using $e$-toll, and many others. Even convenient stores like Indomaret use Kiosk to conduct various transactions, starting from phone recharge balance, ticketing, electricity, buying Google Play applications, health insurance payment, and other services.

It is necessary to further analyze the effectiveness of this technology support by observing how consumers adopt Self Service Technology (SST) in Indonesia. Obvious benefits include faster and more comfortable services, ease-of-use, and advantageous for the consumers. Studies on consumer behavior theory about internet technology's adoption by consumers are included in Theory of Reasoned Action (TRA) by (Fishbein, M., \& Ajzen, 1975). TRA predicts that consumers' attitude and subjective norms influence consumers' intention to perform certain behavior. TRA explains a condition in which consumers have freedom of choice and can conduct any kinds of behaviors under any conditions. However, it cannot explain controlled behavior in which consumers cannot help but performing certain behaviors.

In order to explain the controlled behavior (Ajzen, 1991) posited about Theory of Planned Behavior (TPB) by adding perceived behavioral control, attitude toward behavior, and subjective norms in order to explain consumers' intention to perform certain behavior. There is another model besides TPB which is employed to explain purchase intention, namely Technology Acceptance Model (TAM). TAM was posited by (Fred D. Davis, 1989) to explain user's acceptance on certain technology which is influenced by ease-of-use and perceived usefulness.

Innovation of Diffusion Theory (IDT), which was posited by (Rogers, 1995) explained that innovation and diffusion are adopted by wider social network. Diffusion refers to a process in which innovation is communicated to the members of a social system through different channels. There are 4 elements in diffusion process, namely a) innovation; b) communication channel in which innovation is communicated through different channels; c) time period; d) social system which variably influences diffusion process throughout different periods (Rogers, 1995) TAM and IDT are considered capable of explaining technology adoption. Nevertheless, both theories consider passive consumers as audience-driven in terms of technology, communication channel, and social system. While the truth is, consumers are the customizers and co-producers (Bendapudi, Neeli and Leone, 2003) who can customize their own consumption experience (Fuat Firat, Dholakia and Venkatesh, 1995). Concept and theory about technology adoption discus the external factors surrounding the consumers, not the 
internal driver within consumers themselves. Therefore, all theories mentioned above have not explained what drive consumers to adopt technology based on their respective psychological needs.

As consumers can customize and co-produce for themselves, companies need to understand the role of consumer participation in service and use it to develop their competitive capabilities in the market (Lengnick-Hall, 1996) Self-Determination Theory (hereafter, SDT) refers to motivation theory which explains how human achieves their objectives or performance from their activities based on their psychological and cognitive responses. In SDT terms, psychological and cognitive responses are explained through continuum motivation (Deci and Ryan, 1990) which is categorized into intrinsic motivation, extrinsic motivation, and amotivation.

SDT is a motivation theory that explains the role of global psychological needs in determining human motivation and specific style of motivation (Samy, 2016). It emphasizes the importance of individual freedom in acting on his/her own choice. There is also an intrinsic motivation from oneself, so that when someone is motivated extrinsically and expects external rewards, then the result would be negative (Broeck et al., 2008) Humans have needs to feel competent and have autonomy over their own choices. In other words, human has needs for self-determination.

Humans are described as agents of actions who aim to achieve psychological welfare; hence, each individual has self-determination aspects within his/herself. Self-determination refers to combined motivations within one's characteristics, development, and situational influence to support his/her psychological welfare (Deci and Ryan, 1990; ; Knee et al., 2013) It can be said that self-determination shows behavior which is moved by basic needs (Ryan and Deci, 2000) Based on triangle of psychological needs from Maslow, (Ryan and Deci, 2000) determined that theory of motivation should concentrate on how objectives can be achieved by prioritizing on needs which are valuable for those objectives. SDT concentrates on personal motivation and optimalizes functions which are better than other motivation theories, because SDT focuses on motivation which is categorized in continuum in terms of external motivation.

Cognitive Evaluation Theory (Deci and Ryan, 1990) is one of the theories in SDT and explains about three basic needs underlying intrinsic motivation. Those three basic needs are: a) competence (needs to master an experience which enables individual to face his/her circumstance effectively); b) relatedness (needs for mutually supportive interpersonal relationship); and c) autonomy (needs for making independent decisions regarding important life decisions for each individual). Related to self-service technology, relatedness or interpersonal needs are not needed as consumers need to interact more with technology which provides perceived anonymity.

According (Deci and Ryan, 1990; Ryan and Deci, 2000) motivation is categorized in 3 forms, namely autonomous motivation, controlled motivation, and amotivation. Autonomous motivation lies within oneself and makes human does what she/he needs to do. Someone's acts can be free or autonomous without any pressure from external factors or intrinsic expectation (Knee et al., 2013) Autonomous motivation (or self-determination motivation) includes intrinsic motivation and a type of extrinsic motivation, namely integrated regulation and identified regulation, in which people integrate it with values and activities within themselves. When someone feels motivated autonomously, they obtain self-support and self-advocacy through their activities. Besides intrinsic factor, there is an extrinsic factor involving reward and punishment, namely introjected regulation and external regulation. Extrinsic motivation can explain that if individuals are not interested in the tasks they are supposed to do, it can reduce their self-motivations. 
Based on such background, this reseach aims to observe the influence of psychological needs on consumer intention to adopt self-service technology based on self-determination theory (SDT). This research poses several research questions. First, do human's basic needs (autonomy, competence, and anonymity) influence self-determination motivation; Second, do those basic needs and self-determination motivation influence consumer intention to use selfservice technology.

This research debates about online consumer behavior from a combined perspective between SDT and TRA to analyze the influences of variables like autonomy, competence, perceived anonymity, self-determination motivation, and adoption intention on self-service technology. Theory of Reasoned Action (TRA) is a socio-psychology theory which explains that individual's behavioral intention determines actual behavior. Behavioral intention, in turn, is determined by individual attitude toward behavior and subjective norm, which are related to behavioral performance (Fishbein, M., \& Ajzen, 1975). There are two important variables in TRA, namely attitude and subjective norms. TRA is based on assumptions that individuals continuously take rational choices, while calculating and evaluating relevant beliefs in the process of shaping their attitude toward behaviors. (Fishbein, M., \& Ajzen, 1975) defined attitude as positive or negative perception of individu about certain behavior. Individuals shape their attitude about certain behaviors by evaluating their beliefs through expected-value model. Then, subjective norm is also an important variable in TRA. (Fishbein, M., \& Ajzen, 1975) defined subjective norms' influence occurs when someone (or most people) consider doing something they like or whether they should (or should not) do such behavior based on the perceived social pressure.

Meanwhile, SDT explains that determination refers to mental attitude which is signaled by strong commitment to attain certain objectives despite obstructions and difficulties. It also refers to a process of decision-making, reaching conclusion, and ensuring final results (Broeck et al., 2008)

SDT is a theory which emphasized the importance of individual freedom to act based on his/her choice. There is also intrinsic motivation within oneself, so that when individuals are motivated extrinsically and expected an external reward, then the result shall be negative (Broeck et al., 2008). Humans have needs to feel competent and autonomy about their choices. In other words, humans have needs for self- determination.

There are several factors of basic needs which influence self-determination (Ryan and Deci, 2000) First, autonomy refers to individual freedom to act on his/her choices based on what she/he feels and comes from his/herself. Second, relatedness refers to social relation of individuals in interacting with other individuals in one community and developing mutual interdependence with each other. Lastly, competence refers to individual ability to show what she/he can do and give impacts to their environment.

There are four basic components of mini-theory which is part of self-determination and coordinate with all domains of human behaviors in fulfilling their basic needs. Figure 2.1 below depicts the process of self-organization.

Previous research, which was conducted by (Leung and Matanda, 2013) studied about the influence of human basic needs to use self-service technology in the form of self-service checkout in retail industry. The research connected basic needs which consist of autonomy, competence, relatedness (measured by variable pserceived anonymity) to use self-service technology. When using SST, consumers do not interact with other consumers; thus, it signals perceived anonymity. A study in Australia with Australian respondents resulted in positive relationships between autonomy and competence and self-determination motivation; however, perceived anonymity scored negative relationship with self-determination motivation. It means self-determination motivation has positive relationship with adoption intention. Moreover, all 
variables related to consumers' psychological needs (autonomy, competence, and perceived anonymity) have positive relationship with adoption intention of using self check-out technology.

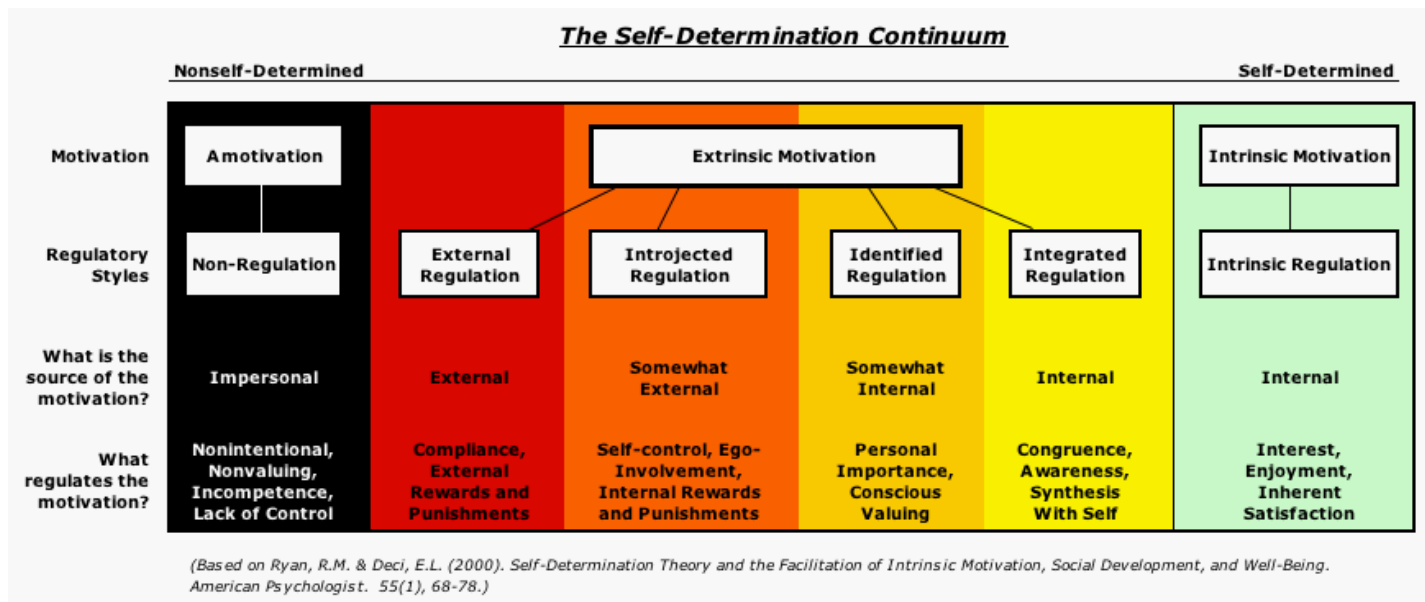

Figure 1. Organismic Integration Theory

Source: Ryan and Decy (2000)

A previous study which was conducted by (Leung and Matanda, 2013)is utilized as the reference for this research on a more general context. Self-service technology is not only applied to food retails, but also to bookstores, railway stations, airline bookings, hotel checkin, and many others. The result of previous study by (Leung and Matanda, 2013) stated that psychological needs (autonomous, competence, and relatedness) significantly influence selfdetermination motivation; while self-determination motivation influences adoption intention of SST.

A study about the relationship between self-determination motivation, behavioral intention, and actual behavior was conducted by (Chatzisarantis et al., 2006) to measure students' intention to exercise. The results showed that physical activities can be well-predicted at an autonomous condition, instead of a scontrolled condition. It means that students do physical activities for autonomous reasons, instead of for appearance's sake (appearance is measured by external regulation and introjected regulation).

Based on the research questions, theoretical framework, thought-process framework, and conceptual framework, the hypotheses of this research are formulated based on the previous studies. Those hypotheses are: a) autonomy, competence, and perceived anonymity influence consumers' self-determination motivation to use self-service technology; b) autonomy, competence, and perceived anonymity, and self-determination motivation influence adoption intention of using self-service technology.

\section{RESEARCH METHODS}

This research was designed as causative research. Its scope encompasses marketing strategy related to marketing communication strategy and consumer behavior in Indonesia, particularly related to the adoption of Self-Service Technology (SST). Exogenous variables included autonomy, competence, and perceived anonymity. Endogenous variable, which acted as a mediator, was self-determination motivation; while another endogenous variable was adoption intention. The research subject was SST and the analysis unit was internet users in Indonesia.

The following operational definitions in this research were adopted from (Leung and Matanda, 2013)study: 
Autonomy (Halvari et al., 2012)referred to a need to make independent decision related to important life aspects of an individual. The indicators were: shopping thoroughly, being fine while making choice to shop, and possibility to shop using self-service technology.

Competence referred to a need to master any experience which enables individuals to face their surroundings effectively. The indicators were: capacity to use, confidence about one's own ability to use', and past experience increases confidence to use self-service technology.

Perceived anonymity is an inversed from relatedness which is pointed to a need of mutually supportive interpersonal relationship. Perceived anonymity referred to a need to not establish any relationship. 'Anonymity' term is used because self-service technology tends not to facilitate interaction between consumers. The indicators were: self-service technology is helpful, do not want anyone to remember anything post-transaction, and do not want to be recognized during purchasing process.

Self-determination motivation referred to motivation which was explained in selfdetermination theory and posited by (Deci and Ryan, 1990) It included:

External regulation $(\boldsymbol{E R})$ which was defined as motivation shaped by external factors, including not receiving any incentives, rewards, or pressures from external parties (Deci and Ryan, 1990)

Introjected regulation (IjR) pointed to consumers' motivation which was derived from internal and external obstacles, including guilt or embarrassment (Deci and Ryan, 1990). One of the indicators was "disappointed if not using self-service technology".

Identified motivation referred to extrinsic motivation where individuals are in controlled state to conduct an act due to external push; however, the individuals tried to integrate it by identifying some aspects (i.e. interests and values) within themselves.

Integrated regulation (InR) referred to motivations created as consumers achieve encouragement and objectives which are in line with the integration with consumers' selfconcepts (Deci and Ryan, 1990)

Intrinsic regulation (IR) referred to a tendency/impulse which merges with consumersselves for hedonic or satisfaction reasons, so that it encourages them to perform certain behaviors (Deci and Ryan, 1990)

Adoption Intention to Self service technology. Operational definition for this research was intention as subjective probability and encouragement owned by someone to purchase via SST.

Furthermore, the population of this research was all internet users in Indonesia. The subject of this research was internet users in Indonesia who have not used self-service technology. Purposive sampling was a technique to determine sampling from non-probability sampling. The number of sample was adjusted using the analytical model of Structural Equation Modelling (SEM). The requirement for SEM's sample size was determined by an estimation model of Maximum Likelihood Estimation (MLE). MLE was determined by multiplying the number of parameters ( 24 parameters) with 10 ; hence, the number of respondents were 240-300 respondents. The respondents' characteristics included in the sample were: internet users in Indonesia who knew about self-service technology yet have not used it; and more than 17 years old. The variables were measured using Likert Scale of 1 to 5.

Moreover, the data collected for this research were primary data. The research was conducted to internet users in Indonesia who fulfilled the respondent criteria. Data collection was conducted by survey using online questionnaire. Online questionnaire was made in GoogleForm and spread to some mailing-lists (discussion groups on the internet). The data were then analyzed using PLS Smart3. 


\section{RESULTS AND DISSCUSION}

The respondents consisted of those more than 17 years old and knew self-service technology, yet have not conducted any transactions using it. 253 data from google form questionnaire collected. There were $34.8 \%$ male respondents and $65.2 \%$ female respondents. Respondents' age varied from 17 years old to 50 years old. There were $70.5 \%$ respondents from 17 to 30 years old; $5.4 \%$ respondents from 31 to 40 years old; $17.5 \%$ respondents from 41 to 50 years old; and $6.7 \%$ respondents more than 50 years old. Moreover, the education level of respondents showed that most of them graduated from high school $(54.2 \%)$, and followed by bachelor degree graduates $(32.1 \%)$. Approximately $85.3 \%$ of respondents are welleducated, so it can be used as a reference for their behaviors as potential consumers.

Measurement of validity was conducted by calculating the score of composite reliability in which all values of cronbach alpha were more than 0.7 ; thus, it can be said that all constructs fulflled composite reliability criteria. Convergent validity was known as another term, namely reliability indicators (Hair and Black, William, Babin, Barry J., Anderson, 2014). Based on the calculation results of convergent validity (outer loading), all outer loading coefficients scored more than 0.5; hence, it can be said that all indicators fulfilled convergent validity. All AVE values were more than 0.5 ; thus, it can be said that all variables fulfilled convergent validity.

According to indicators (Hair and Black, William, Babin, Barry J., Anderson, 2014).discriminant validity was calculated based on cross loading and Foenell-Larcher Criterion. The calculation result of attitude's cross loading correlation with its own indicators was higher than attitude's correlation with other constructs' indicators. The square root value of AVE was higher than other correlation values with other variables; hence, it was said that the model was valid and fulfilled discriminant validity. Moreover, outer loading values displayed each weight of each indicator as the measurement of each latent variable.

VIF values between predictors of latent variables were higher than 0.2 and lower than 5; hence, it can be said that collinearity did not occur in the structural model. The test of goodness-of-fit was conducted using predictive relevance (Q2) . Stone-Geisser's values of $Q^{2}$ (Stone, 1974; Geissser, 1975) were criteria used to measure the accuracy of prediction, besides using $\mathrm{R}^{2}$ value. This measurement was relevance indicator of the model. The value of $\mathrm{Q}^{2}$ for adoption intention variable was 0.572 ; while the $\mathrm{Q}^{2}$ for self-determination value was 0.488 . Both values of $\mathrm{Q}^{2}$ from two endogenous variables were larger than 0.32 ; hence, it can be said that predictive relevances for 2 variables were significant. It also implied that exogenous variables (anonymity, autonomy, and competence) had significant predictive relevances over self-determination; while the predictive relevances of the exogenous variables (anonymity, autonomy, and competence) and self-determination had significant predictive relevance over adoption intention. Moreover, the value of $\mathrm{Q}^{2}$ for adoption intention was the highest one. It explained that putting adoption intention in the structural model as the ultimate endogen was accurate.

After measurement model was deemed valid and reliable, the next step was to measure structural model to connect autonomy, competence, perceived anonymity, self-determination, and adoption intention. The structural model is depicted in Figure 4.1 as follows:

The influence of independent variable on dependent one, just like in regression equation, can be measured from the value of determination coefficient in which the influence of independent variable on dependent variable can be analyzed. The value of coefficient determination for adoption intention was 0.622 , signifying that autonomy, competence, perceived anonymity, and self-determination strongly influenced adoption intention to conduct purchase using SST. The value of coefficient determination for self-determination was 0.771 , 
implying that autonomy, competence, and perceived anonymity significantly influenced selfdetermination to purchase using SST.

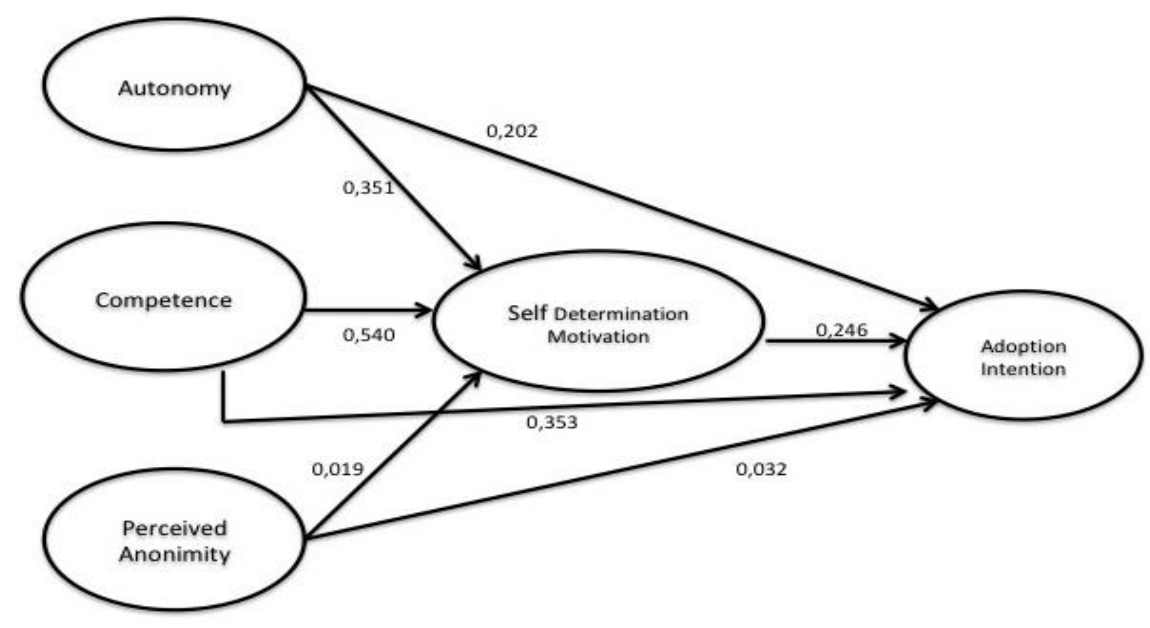

Figure 2. Results of Structural Equation

Furthermore, effect size referred to valuation of prediction strength of the model $\left(\mathrm{f}^{2}\right)$. The influence of $\mathrm{f}^{2}$ can be employed to measure the strength of influence of exogenous latent variables on endogenous variables on the model. The exogenous variable, anonymity, insignificantly affected adoption intention; while its influence on self-determination was insignificantly small. Moreover, the influence of autonomy on adoption intention was adequately significant, so did its influence on self-determination. The influence of competence on adoption intention and self-determination were both adequately significant; while selfdetermination's influence on adoption intention was also adequately significant.

The evaluation of Inner Model's coefficients and hypotheses testing is illustrated in Figure 1 and Table 1. The relationship between variables was explained based on the results of path coefficient values which were obtained from bootstrapping process.

The path coefficient values for autonomy, competence, and anonymity toward selfdetermination and adoption intention, show positive relationships between these three basic needs variables in self-determination and adoption intention. The relationship between selfdetermination and adoption intention is positive.

There were 7 (seven) hypotheses tested to view the influences between variables and to test mediating effects based on bootstrapping's path coefficients values. The results showed that autonomy and competence influenced self-determination; while anonymity had no influence on self-determination, indicating that hypothesis was rejected. Moreover, autonomy, competence, and self-determination influenced adoption intention. There was no influence from perceived anonymity on adoption intention, indicating that the hypothesis was rejected.

There was indirect and significant influences of autonomy and competence on adoption intention through self-determination. However, there was no significant and indirect influence from perceived anonymity on adoption intention through self-determination. The VAF value of autonomy was recorded at 0.298611111 , indicating that the role of self-determination as mediator was partial mediation because the value of VAF varied between 0.2 and 0.8 . Moreover, the VAF value of competence was approximately 0.273662551 , signaling that the role of self-determination as mediator was partial mediation, because the value of VAF hovered between 0.2 and 0.8. Lastly, the value of VAF for anonymity was around 0.135135135, indicating that as a mediator, self-determination scored small mediation role as the value of VAF was less than 0.2. 
This research focuses on technology adaptation theories, namely TAM, TPB dan IDT (Davis, Bagozzi and Warshaw, 1989) specifically on the use of SST. This study supports the arguments that consumer behavior in using self-service technology is influenced and motivated by their basic human needs. It is consistent with the arguments of self-determination theory by (Ryan and Deci, 2000). Moreover, this study explains that self-determination's motivation is related to adoption intention of SST, supporting the arguments that self-regulation (or consumer autonomy) drives vitality or energy availability within oneself ((Deci and Ryan, 2008). This energy drives consumers' adoption intention of SST. This finding supports the arguments that if consumers' motivation is autonomous, then their behaviors shall be more internalized and persistent ((Ryan and Deci, 2000) It is consistent with the findings from (Williams et al., 1998; Baard, Deci and Ryan, 2004); Autonomy is positively associated with adoption intention of SST. This finding states that in the context of controlled internalization process, autonomy in social context can drive internalization.

Table 1. The Results of Hypothesis Testing for Inner Model (Inter-Variable Influence Based on Bootstrapping Process)

\begin{tabular}{|c|c|c|c|c|c|c|c|}
\hline & Direct Effect & & & & Indirect Eff & & \\
\hline Hypothesis & $\begin{array}{l}\text { Inter-variable } \\
\text { relationship }\end{array}$ & Coefficient & $\begin{array}{l}t- \\
\text { statistics }\end{array}$ & Remarks & Coefficient & $\begin{array}{l}t- \\
\text { statistics }\end{array}$ & Remarks \\
\hline H1 & $\begin{array}{l}\text { Autonomy } \rightarrow \\
\text { Self- } \\
\text { determination }\end{array}$ & 0.351 & 3.910 & $\begin{array}{l}\text { Hypothesi } \\
\mathrm{s} \\
\text { accepted. }\end{array}$ & & & \\
\hline $\mathrm{H} 2$ & $\begin{array}{l}\text { Competence } \rightarrow \\
\text { Self- } \\
\text { determination }\end{array}$ & 0.540 & 7.385 & $\begin{array}{l}\text { Hypothesi } \\
\mathrm{s} \\
\text { accepted. }\end{array}$ & & & \\
\hline H3 & $\begin{array}{l}\text { Anonymity } \rightarrow \\
\text { Self- } \\
\text { determination }\end{array}$ & 0.019 & 0.328 & $\begin{array}{l}\text { Hypothesi } \\
\text { s rejected. }\end{array}$ & & & \\
\hline $\mathrm{H} 4$ & $\begin{array}{l}\text { Autonomy } \rightarrow \\
\text { adoption } \\
\text { intention }\end{array}$ & 0.202 & 2.233 & $\begin{array}{l}\text { Hypothesi } \\
\text { s } \\
\text { accepted. }\end{array}$ & 0.086 & 2.081 & $\begin{array}{l}\text { Mediating } \\
\text { variable of } \\
\text { self- } \\
\text { determination } \\
\text { is significantly } \\
\text { influential. } \\
\end{array}$ \\
\hline H5 & $\begin{array}{l}\text { Competence } \rightarrow \\
\text { adoption } \\
\text { intention }\end{array}$ & 0.353 & 3.926 & $\begin{array}{l}\text { Hypothesi } \\
\text { s } \\
\text { accepted. }\end{array}$ & 0.133 & 2.443 & $\begin{array}{l}\text { Mediating } \\
\text { variable of } \\
\text { self- } \\
\text { determination } \\
\text { is significantly } \\
\text { influential. }\end{array}$ \\
\hline H6 & $\begin{array}{l}\text { Anonimity } \rightarrow \\
\text { adoption } \\
\text { intention }\end{array}$ & 0.032 & 0.511 & $\begin{array}{l}\text { Hypothesi } \\
\text { s rejected. }\end{array}$ & 0.005 & 0.309 & $\begin{array}{l}\text { Mediating } \\
\text { variable of } \\
\text { self- } \\
\text { determination } \\
\text { is not } \\
\text { significantly } \\
\text { influential. }\end{array}$ \\
\hline $\mathrm{H} 7$ & $\begin{array}{l}\text { Self- } \\
\text { determination } \\
\rightarrow \quad \text { adoption } \\
\text { intention }\end{array}$ & 0.246 & 2.560 & $\begin{array}{l}\text { Hypothesi } \\
\text { s } \\
\text { accepted. }\end{array}$ & & & \\
\hline
\end{tabular}

Source: Print-out of PLS

Based on the results of this study, the influences of autonomy and adoption intention of 
SST have more significant effects than indirect effects from the mediating of selfdetermination's motivation. Moreover, autonomy explains the direct effects of those variables on adoption intention of SST. It also drives internalization and self-determination's motivation. The results indicate that accommodating consumers' lifestyle and developing consumer choice to choose SST can improve the use of SST on retail context. This finding is consistent with the findings from; Dab Hol Kan and Bagozy (2002); Higgins and Spiergel (2004); Twenge and Baumuter (2005); Wagener and Wang et al. (2013); William et al. (1998).

In this study, competence positively influences adoption intention and selfdetermination motivation. It implies that when individuals feel more confident, their behaviors shall be more effective. They shall also have more satisfaction, which lead to user-focused behavior and self-determination. It indicates that competence both directly and indirectly influences adoption intention through self-determination motivation. Moreover, competence had significant influence through internalization which drives purchase intention through SST.

While perceived anonymity showed insignificant influence on self-determination motivation, which is consistent with the arguments about SDT in the studies of (Baumeister, Twenge and Nuss, 2002; Higgins, E. T., \& Spiegel, 2004). It shows that relatedness is important to enhance individuals' sense of belonging and plays a role in the process of value internalization and practices. This finding indicates that perceived anonymity has an inversed effect on relatedness and avoids internalization process of SST.

Perceived anonymity positively, yet insignificantly influenced adoption intention. This result is not consistent with the findings of (Joinson, 1999)which stated that anonymity reduces social anxiety and drives consumers' self-esteem, as well as makes consumers consider using SST. Perceived anonymity showed indirect and insignificant effects on adoption intention of SST through self-determination motivation and adoption intention. It proves that commitment to use SST is derived from the need of self-anonymity and preference toward unidentified transactions. Non-existent contact with customer service staffs influences consumer's selfdetermination, although it is not significant and influential to the intention to use SST.

Competence has the largest influence on the internalization process, compared to autonomy and perceived anonymity. It is proven when autonomy, competence, and perceived anonymity directly influence purchase intention of SST without needing any internalization process, particularly in terms of autonomy. Therefore, self-determination motivation partially mediates the relationship between autonomy, competence, perceived anonymity, and adoption intention toward SST. Based on these results, retail managers should not only focus on enhancing SST features and understanding communication channel, period, and system influencing SST; but also improving SST based on consumers' basic needs, including autonomy, competence, and perceived anonymity.

Focus on these needs can drive internalization process, consumers autonomy, and selfdetermination motivation, which later lead to developing consumer intention to use SST. When the company develops autonomy in this context, managers should not only develop comfortable store experience, but also putting several self check-out machines in order to provide benefits to the store. For instance, managers should not reduce the number of counters at the store in order to reduce cost or store facilities. If counters serviced by human staffs are reduced, consumers will encourage themselves to use SST machines, because their selfdetermination and motivation and adoption intention toward SST are enhanced. Consumers are supposed to be able to make choices, whether they want to be served by SST or staffs; because using SST should have accommodated consumers' lifestyle differences. Stores should develop adequate shopping choices for the consumers; hence, SST machines should never be the only choice offered by the stores. The stores should offer optimal support and service for the consumers in using SST, because consumers who can use the system can influence 
internalization process.

Furthermore, competence is important in consumers' internalization process. When consumers feel more confident, they will find out that using SST is more effective and develops more preference to use it in the future. Management should offer some trainings in order to enhance consumers skill in using SST. When the consumers become more skilled, they would be more confidence in using SST, so that management's investment for SST services will not be in vain. Moreover, the procedure to use SST also needs to be more simple and easier to understand for consumers.

As some suggestions, managers shoud not reduce the staffs who are responsible for helping consumers to use SST machine. This approach will reduce some possibilities for faceto-face interaction between consumers and consumer service staffs. A disruption in internalization process should influence the use of SST machines among consumers. Therefore, managers should develop optimal interaction between consumers and consumer service staffs. The staffs should help consumers using SST machine and make them comfortable using it until they feel confident and can independently use it in the future.

This study successfully fills in theoretical gap from literature by using SDT which is applied to retail context and explains the phenomena of SST usage among consumers by linking it with basic human needs. However, the limit of this research lies in the number of human basic needs which was employed in it. Human needs do not merely encompass 3 variables, but also include trust (Shelat and Egger, 2002) and novelty (Agarwal and Prasad, 1998; Robinson, L., Marshall, G.W., Stamps, 2005)). Hence, further research about other human basic needs after the adoption of SST.

\section{CONCLUSION}

There are four findings for this research. First, autonomy and competence positively influence self-determination. Second, anonymity does not positively influence selfdetermination. Third, autonomy, competence, and self-determination positively influence adoption intention. Lastly, anonymity does not positively influence adoption intention.

Therefore, online retailers should improve their strategies to enhance consumers' intrinsic and extrinsic motivations by providing different ways of selling products and better than conventional methods. It implies that companies which sell their product online should employ SST by paying attention to information quality, system quality, and service quality. Information quality should be provided by ensuring that the information content is high quality, helpful, detailed, and updated. While system quality is related to ease-of-use, so the transaction process should be easy. Finally, service quality should be reliable and trustworthy.

\section{REFFERENCE}

Agarwal, R. and Prasad, J. (1998) 'A Conceptual and Operational Definition of Personal Innovativeness in the Domain of Information Technology', Information Systems Research, 9(2), pp. 204-215. doi: 10.1287/isre.9.2.204.

Ajzen, I. (1991) 'Ajzen, I. (1991). The theory of planned behavior. Organizational Behavior and Human Decision Processes, 50(2), 179-211. doi:10.1016/0749-5978(91)90020-t', ORGANIZATIONAL BEHAVIOR AND HUMAN DECISION PROCESSES, 50,(2), pp. 179-211. Available at: doi:10.1016/0749-5978(91)90020-t.

Baard, P. P., Deci, E. L. and Ryan, R. M. (2004) 'Intrinsic need satisfaction: A motivational basis of performance and well-being in two work settings', Journal of Applied Social Psychology, 34(10), pp. 2045-2068. doi: 10.1111/j.1559-1816.2004.tb02690.x.

Baumeister, R. F., Twenge, J. M. and Nuss, C. K. (2002) 'Effects of social exclusion on cognitive processes: Anticipated aloneness reduces intelligent thought', Journal of 
Personality and Social Psychology, 83(4), pp. 817-827. doi: 10.1037/00223514.83.4.817.

Bendapudi, Neeli and Leone, R. P. (2003) 'Psychological Implications of Mastectomy', Australian and New Zealand Journal of Surgery, 51(3), pp. 300-303. doi: 10.1111/j.1445-2197.1981.tb05962.x.

Broeck, V. Den et al. (2008) 'Self-determination theory ( SDT )', 3.

Chatzisarantis, N. L. D. et al. (2006) 'The influences of intrinsic motivation on execution of social behaviour within the theory of planned behaviour', European Journal of Social Psychology, 36(2), pp. 229-237. doi: 10.1002/ejsp.299.

Davis, F. D., Bagozzi, R. P. and Warshaw, P. R. (1989) 'User Acceptance of Computer Technology: A Comparison of Two Theoretical Models', Management Science, 35(8), pp. 982-1003. doi: 10.1287/mnsc.35.8.982.

Deci, E. L. and Ryan, R. M. (1990) 'A motivational approach to self: integration in personality.', Nebraska Symposium on Motivation. Nebraska Symposium on Motivation, 38(February), pp. 237-288.

Deci, E. L. and Ryan, R. M. (2008) 'Facilitating optimal motivation and psychological wellbeing across life's domains', Canadian Psychology, 49(1), pp. 14-23. doi: 10.1037/0708-5591.49.1.14.

Fishbein, M., \& Ajzen, I. (1975) Belief, attitude, intention, and behavior : An introduction to theory and research. Reading, Mass. ; Don Mills. Ontario: Addison-Wesley Pub. Co.

Fred D. Davis (1989) 'Perceived Usefulness, Perceived Ease of Use, and User Acceptance of Information Technology', MIS Quarterly, 13(3), pp. 319-340. doi: 10.1016/j.cell.2017.08.036.

Fuat Firat, A., Dholakia, N. and Venkatesh, A. (1995) 'Marketing in a postmodern world', European Journal of Marketing. MCB UP Ltd, 29(1), pp. 40-56. doi: 10.1108/03090569510075334.

Geissser, S. (1975) 'No Title: The predictive samples reuse method with applications', Journal of the American Statistical Association, 70.

Hair, J. F. and Black, William, Babin, Barry J., Anderson, R. E. (2014) Univariate Data Analysis, Exploratory Data Analysis in Business and Economics. doi: 10.1007/978-3319-01517-0_3.

Halvari, A. E. M. et al. (2012) 'Self-determined motivational predictors of increases in dental behaviors, decreases in dental plaque, and improvement in oral health: A randomized clinical trial', Health Psychology, 31(6), pp. 777-788. doi: 10.1037/a0027062.

Higgins, E. T., \& Spiegel, S. (2004). (p. 171-187). T. G. P. (2004) 'Promotion and prevention strategies for self-regulation: A motivated cognition perspective. In R. F. Baumeister $\&$ K. D. Vohs (Eds.), Handbook of self-regulation: Research, theory, and applications', Handbook of self-regulation: Research, theory, and applications.

Joinson, A. (1999) 'Social desirability, anonymity, and Internet-based questionnaires', Behavior Research Methods, Instruments, and Computers, 31(3), pp. 433-438. doi: 10.3758/BF03200723.

Knee, C. R. et al. (2013) 'Self-Determination Theory and Romantic Relationship Processes', Personality and Social Psychology Review, 17(4), pp. 307-324. doi: 10.1177/1088868313498000.

Lengnick-Hall, C. A. (1996) 'Customer contributions to quality', Academy of Management Review, 21(3), pp. 724-791. Available at: http://search.ebscohost.com/login.aspx?direct=true \&db=epref\&AN=AMR.BA.GIA.L ENGNICKHALL.CCQ\&lang=fr\&site=bsi-live.

Leung, L. S. K. and Matanda, M. J. (2013) 'The impact of basic human needs on the use of 
retailing self-service technologies: A study of self-determination theory', Journal of Retailing and Consumer Services. Elsevier, 20(6), pp. 549-559. doi: 10.1016/j.jretconser.2013.06.003.

Robinson, L., Marshall, G.W., Stamps, M. . (2005) 'Sales Force Use of Technology: Antecedents To Technology Acceptance', Journal of Business Research, 58(12), pp. $1623-1631$.

Rogers, E. M. (1995) 'Diffuison of Innovations', Elements of Diffusion 3rd. Edition. 4th edn. Edited by Auflage. New York: The Free Press, pp. 1-37. doi: citeulike-articleid: 126680 .

Ryan, R. M. and Deci, E. L. (2000) 'Intrinsic and Extrinsic Motivations: Classic Definitions and New Directions', Contemporary Educational Psychology, 25(1), pp. 54-67. doi: 10.1006/ceps.1999.1020.

Samy, R. N. (2016) 'Adoption of new technology', Current Opinion in Otolaryngology and Head and Neck Surgery, 24(5), p. 381. doi: 10.1097/MOO.0000000000000298.

Shelat, B. and Egger, F. N. (2002) 'What makes people trust online gambling sites?', p. 852. doi: $10.1145 / 506621.506631$.

Stone, M. (1974) 'Cross-Validatory Choice and Assessment of Statistical Predictions', Journal of the Royal Statistical Society: Series B (Methodological), 36(2), pp. 111-133. doi: 10.1111/j.2517-6161.1974.tb00994.x.

Williams, G. C. et al. (1998) 'Autonomous regulation and long-term medication adherence in adult outpatients.', Health Psychology, 17(3), pp. 269-276. doi: 10.1037//02786133.17.3.269. 
QUESTIONNAIRE ITEMS

\begin{tabular}{|c|c|c|}
\hline \multicolumn{3}{|c|}{ AUTONOMY } \\
\hline AUTO1 & $=$ & I think I can thoroughly shop if I use self-service technology \\
\hline AUTO2 & $=$ & I think I am fine if I can make shopping choices using self-service technology \\
\hline AUTO3 & $=$ & I think it is possible for me to shop using self-service technology \\
\hline \multicolumn{3}{|c|}{ COMPETENCE } \\
\hline COMPETE1 & $=$ & I am really skilled at using self-service technology \\
\hline COMPETE2 & $=$ & I am confident I can use self-service technology \\
\hline COMPETE3 & $=$ & Past experience increases my confidence to use self-service technology \\
\hline \multicolumn{3}{|c|}{ PERCEIVED ANONIMITY } \\
\hline ANONIM1 & $=$ & Self-service technology helps me \\
\hline ANONIM2 & $=$ & I do not want anyone else remembers anything [about me] after I shop at a store \\
\hline ANONIM3 & $=$ & I do not want to be recognized during purchasing process \\
\hline \multicolumn{3}{|c|}{ SELF-DETERMINATION MOTIVATION } \\
\hline EXTERN1 & $=$ & After I go shopping, my family wants me to go home soon. \\
\hline EXTERN2 & $=$ & I do not want my family feels tired if I ask them to go out to shop. \\
\hline EXTERN3 & $=$ & I do not want to see elderly queueing for a long time. \\
\hline IDENT1 & & Using self-service technology is important. \\
\hline IDENT2 & & Using self-service technology provides benefits. \\
\hline IDENT3 & & Using self-service technology is wise \\
\hline INTOJECT1 & $=$ & I feel inadequate if I do not use self-service technology to fulfill my interest. \\
\hline INTOJECT2 & $=$ & I feel disappointed with myself if I do not use self-service technology. \\
\hline INTOJECT3 & $=$ & I feel uncomfortable if I do not use self-service technology \\
\hline INTEGR1 & $=$ & Using self-service technology is a well-integrated habit in my life. \\
\hline INTEGR2 & $=$ & Using self-service technology for shopping is a natural thing for me. \\
\hline INTEGR3 & $=$ & Using self-service technology becomes a habit in my life. \\
\hline INTRIN1 & $=$ & I enjoy using self-service technology. \\
\hline INTRIN2 & $=$ & I think using self-service technology giving me an enjoyable experience. \\
\hline INTRIN3 & $=$ & I like the feeling when I use self-service technology. \\
\hline \multicolumn{3}{|c|}{ ADOPTION INTENTION } \\
\hline ADOPINT1 & $=$ & I intent to use self-service technology to use self-service technology. \\
\hline ADOPINT2 & $=$ & I plan to use self-service technology to use self-service technology. \\
\hline ADOPINT3 & $=$ & I will recommend my friends and relatives to use self-service technology. \\
\hline
\end{tabular}

